\title{
Identification, Virulence and Fungicide Sensitivity of Colletotrichum gloeosporioides s.s. Responsible for Walnut Anthracnose Disease in China
}

\author{
Qing-Hai Wang, ${ }^{1,2}$ Kun Fan, ${ }^{3}$ De-Wei Li, ${ }^{2,4}$ Chuan-Ming Han, ${ }^{1}$ Yong-Yun Qu, ${ }^{1}$ Yu-Kun Qi, ${ }^{1}$ and Xiao-Qin $\mathrm{Wu}^{2, \dagger}$ \\ ${ }^{1}$ Shandong Provincial Academy of Forestry, Jinan, Shandong 250014, China \\ ${ }^{2}$ Co-Innovation Center for Sustainable Forestry in Southern China, College of Forestry, Nanjing Forestry University, Nanjing, \\ Jiangsu 210037, China \\ ${ }^{3}$ Shandong Institute of Pomology, Taian, Shandong 271000, China \\ ${ }^{4}$ The Connecticut Agricultural Experiment Station Valley Laboratory, Windsor, CT 06095, U.S.A.
}

\begin{abstract}
Walnut (Juglans regia L.) is an economically important woody nut and edible oil tree all over the world. However, walnut production is limited by walnut anthracnose, which is a disastrous disease that causes significant yield losses. Studying the etiology of anthracnose on walnut and the pathogens' virulence and sensitivities to fungicides would be beneficial for effective control. This study was conducted to identify the pathogen of walnut anthracnose and reveal the population diversity of pathogens through virulence, sensitivities to fungicides, and genetic variation. A total of 13 single-spore Colletotrichum isolates were collected from walnut anthracnose-diseased fruits and leaves from 13 walnut commercial orchards in Henan, Hubei, Shandong, and Shaanxi provinces in China. The isolates were identified as Colletotrichum gloeosporioides sensu stricto (s.s.) according to multilocus phylogenetic analyses (internal transcribed spacer, actin, glyceraldehyde-3-phosphate dehydrogenase, and chitin synthase), morphological as well as cultural characters, and pathogenicity. When the same walnut tissue was inoculated with different isolates, the disease lesion size was different. The results showed that the virulence of all isolates was considerably different, and the differences were not correlated with geographic origins. The virulence to walnut leaves and fruits inoculated with the same isolate was significantly

difference in pathogenicity, and the virulence to walnut leaves was higher for $15.4 \%$ of isolates. Tebuconazole, difenoconazole, flusilazole, and carbendazim inhibited the growth of fungal mycelia, and the concentration for $50 \%$ of maximal effect $\left(\mathrm{EC}_{50}\right)$ values were 0.4 to $20.5,0.6$ to 2.6, 0.2 to 1.6 , and 0.002 to $0.2 \mu \mathrm{g} / \mathrm{ml}$, respectively, with average values of $6.5 \pm 6.9,1.5 \pm 0.6,0.9 \pm 0.4$, and $0.1 \pm 0.05 \mu \mathrm{g} / \mathrm{ml}$, respectively. All isolates were more sensitive to difenoconazole, flusilazole, and carbendazim than tebuconazole $(P<0.01)$. Isolate sensitivities to the same fungicide were different. Isolates SL-31 and TS-09 were the least sensitive to carbendazim and tebuconazole, respectively, and the resistance ratios were 87.3 and 51.6, respectively. Sensitivities to difenoconazole and flusilazole were largely consistent among all isolates, and the resistance ratios were from 1 to 4.6 and from 1 to 7 , respectively. Therefore, difenoconazole and flusilazole could be chosen for disease control. The differences of pathogenicity and fungicide sensitivity were not correlated with geographic regions. These results indicated that there was high intraspecific diversity of populations in C. gloeosporioides s.s. that caused walnut anthracnose. For effective management, the targeted control strategy should be implemented based on the different geographic regions.
\end{abstract} different. Based on the virulence to walnut leaves and fruits, the 13 isolates were divided into three groups. Virulence of $69.2 \%$ of the isolates to walnut fruits was higher than that to leaves; $15.4 \%$ of isolates had no
Keywords: coelomycete, diversity, juglans, multilocus phylogeny, pathogenicity, resistance ratio
Walnut (Juglans regia L.) is an important woody nut and edible oil tree throughout the world. Walnut trees are planted largely for their nuts, which are mainly used for food and oil expression (Blomhoff et al. 2006; Cortés et al. 2006). Walnut production is threatened by several insects and diseases (Khan and Kundoo 2018; Tian et al. 1991; Wang and Tang 2018). Among these diseases, anthracnose disease caused by Colletotrichum spp. is a crucial constraint to walnut production in many walnut-planting areas in the world, and it often results in huge yield losses and even total losses in some walnut orchards (Da Lio et al. 2018; Wang et al. 2016). In Shandong province, China, walnut anthracnose occurred from late June to harvest.

${ }^{\dagger}$ Corresponding author: X.-Q. Wu; xqwu@njfu.edu.cn

Funding: This work was supported by National Key Research and Development Program of China grant 2017YFD0600104, Priority Academic Program Development of Jiangsu Higher Education Institutions grant PAPD, and Science and Technology Development Project in Shandong Province grant 2012 GGB22004.

*The $\boldsymbol{e}$-Xtra logo stands for "electronic extra" and indicates that two supplementary figures and one supplementary table are published online.

The author(s) declare no conflict of interest.

Accepted for publication 20 December 2019.

() 2020 The American Phytopathological Society
The spots were about 5 to $10 \mathrm{~mm}$ in diameter in mid- to late July. Some spots were merged into large necrotic areas in the middle of August, and the fruits and leaves failed to develop normally or dropped prematurely. The fruits and leaves infected in August would shed in a large area before harvest (late August to early September) (Zhu et al. 2014).

The genus Colletotrichum Corda is one of the most important and destructive plant pathogens worldwide. From the perspective of scientific and economic significance, the genus Colletotrichum was considered as the eighth most important group of phytopathogenic fungi worldwide (Dean et al. 2012) and could attack $>3,200$ species of monocot and dicot plants (Manire et al. 2002; O'Connell et al. 2012), including many crops of cereals, fruits, vegetables, and ornamentals (Cannon et al. 2012; Damm et al. 2010; Honger et al. 2016; Huang et al. 2016). Several species of the genus Colletotrichum have been isolated from J. regia, such as Colletotrichum gloeosporioides sensu lato in Korea, Japan, New Zealand, and South Africa (Chen 2003; Cho and Shin 2004; Crous et al. 2000; Gadgil et al. 2005; Gorter 1977; Kobayashi 2007; Pennycook 1989); Colletotrichum sp. in Mexico (Alvarez 1976); C. gloeosporioides from walnut fruits in Slovenia, which caused spots on green walnut fruits (Juhásová et al. 2005); Colletotrichum godetiae in Australia (Damm et al. 2012); Colletotrichum acutatum in Australia (Simmonds 1966); and C. acutatum sensu lato (s.l.; geographic origin and pathogenicity were unknown) (Sreenivasaprasad and Talhinhas 2005). In France, Colletotrichum fioriniae, Colletotrichum nymphaeae, C. godetiae, and $C$. gloeosporioides s.l. were isolated from walnut leaves, nuts, and buds, and they were confirmed to be the pathogens of walnut 
anthracnose, which were identified by multigene phylogenetic analysis (Da Lio et al. 2018). In Brazil, C. nymphaeae caused walnut anthracnose (Savian et al. 2019). In China, C. gloeosporioides sensu lato (Chen 2003; Qu et al. 2011), C. acutatum (Liu et al. 1995), C. fioriniae (Zhu et al. 2015), Colletotrichum siamense (Wang et al. 2017), Colletotrichum fructicola (Wang et al. 2018), and Colletotrichum viniferum (He et al. 2019) were isolated from walnut. The pathogen of walnut anthracnose was not only C. gloeosporioides but also, $C$. fructicola and $C$. siamense (Wang et al. 2017, 2018) in China. C. fioriniae could infect walnut leaves, and the symptoms were similar to anthracnose (Zhu et al. 2015). C. viniferum only infected walnut leaves, and the symptoms were not typical (He et al. 2019).

There was a difference in pathogenicity of Colletotrichum isolates. Zhang et al. (2014a) considered that the pathogenicity of the genus Colletotrichum from different sources to the same litchi cultivar was different. The virulence of $C$. siamense to walnut fruits was not consistent with that to leaves (Wang et al. 2017). Chemical control methods are the most commonly used strategies against anthracnose. These reports showed that the $C$. gloeosporioides causing grape ripe rot was resistant to thiophanate-methyl and diethofencarb (Chen et al. 2013). C. gloeosporioides isolates from mango, litchi, longan, etc. in Hainan province showed high resistance to carbendazim (Zhang et al. 2014b). However, any differences in fungicide sensitivities of isolates causing walnut anthracnose remain unknown. There were abundant interspecies and intraspecific diversities of populations. The genetic diversity of grape anthracnose pathogens in Yunnan province was complex and inconsistent with geographic origins, host specificities, colony or spore morphologies, and pathogenicity to red globe grape (Deng et al. 2015). The diversity of populations of the isolates, which caused anthracnose in tea and other woody plants in Fujian province, was consistent with host specificities, not with geographic origins (Liu et al. 2017). The genetic differences of walnut anthracnose pathogens are largely unknown.

The objectives of this study were (i) to identify the species of the genus Colletotrichum causing walnut anthracnose using multilocus phylogenetic analyses and morphological characteristics, (ii) to determine the pathogenicity of the isolates obtained from walnut fruits and leaves in China, and (iii) to examine the sensitivity of isolates to four fungicides (tebuconazole, difenoconazole, flusilazole, and carbendazim) using in vitro methods.

\section{Materials and Methods}

Plant materials, pathogen isolation, and purification. From 2013 to 2014, walnut fruits and leaves with anthracnose symptoms were collected from 13 walnut orchards in Henan, Hubei, Shaanxi, and Shandong provinces in China (Table 1).

Pure cultures were obtained from diseased walnut fruits and leaves as well as from single-spore isolation. The walnut fruits and leaves were surface sterilized with $70 \%$ ethanol, and margins of the healthy and diseased tissues were cut into 3 - to $4-\mathrm{mm}^{2}$ segments. The segments were sterilized with $1 \% \mathrm{NaOCl}$ for $60 \mathrm{~s}$ and $70 \%$ ethanol for $60 \mathrm{~s}$, and they were washed in sterile distilled water three times. Five segments were placed on potato dextrose agar (PDA; $1.5 \%$, DifcoBD Diagnostics) and incubated at $28^{\circ} \mathrm{C}$. Seven days later, hyphae were transplanted to PDA plates for sporulation. Using serial dilution, monosporic isolates were obtained (Choi et al. 1999; Than et al. 2008) and stored at $4^{\circ} \mathrm{C}$ on PDA slants. Most of the isolates were stored and preserved in the China Forestry Culture Collection Center (Table 2).

Morphological analysis. The isolates were cultured on PDA at $28^{\circ} \mathrm{C}$ for 5 days. The colony color, conidial masses, and zonation were observed and documented. A drop of sterile water was placed on a glass slide, and then, three acervuli were placed on the slide and gently crushed under a cover glass; a few drops of cedar oil were added under the cover glass to decrease water evaporation. Appressoria developed on the surface of the glass slide. Acervuli, conidia, appressoria, conidiophores, and conidiogenous cells were observed under a compound microscope (Nikon Eclipse 50i), and photomicrographs were taken with a highresolution QImaging camera system (QImaging); the sizes of conidia and appressoria were measured by cellSens standard software (Olympus).

DNA extraction, amplification, sequencing, and phylogenetic analyses. Mycelia (growing for 5 days on PDA) were dried with sterile filter paper and collected in a sterile centrifuge tube. Mycelial powder was obtained by the trituration method in liquid nitrogen.

Table 1. The walnut anthracnose sample geographic distribution, walnut varieties, and damage degree

\begin{tabular}{|c|c|c|c|c|c|c|}
\hline No. & Isolate & Orchard location & Longitude and latitude coordinate & Varieties & Damage degree $^{\mathrm{z}}$ & Disease sample \\
\hline 1 & SMX-42H & $\begin{array}{l}\text { Nanlupo village, Cizhong town, } \\
\text { Sanmenxia city, Henan province }\end{array}$ & $\mathrm{N}: 34^{\circ} 44^{\prime} 07.7^{\prime \prime} \mathrm{E}: 111^{\circ} 18^{\prime} 07.4^{\prime \prime}$ & Cultivar Liaohe & ++ & Leaf \\
\hline 2 & TS-09 & $\begin{array}{l}\text { Haojiazhuang village, Qiujiadian town, } \\
\text { Taian city, Shandong province }\end{array}$ & $\mathrm{N}: 36^{\circ} 10^{\prime} 01.1^{\prime \prime} \mathrm{E}: 117^{\circ} 14^{\prime} 53.3^{\prime \prime}$ & Cultivar Xiangling & ++++ & Fruit \\
\hline 3 & SQ-141 & $\begin{array}{l}\text { Daoshanyu village, Shuangquan town, } \\
\text { Jinan city, Shandong province }\end{array}$ & $\mathrm{N}: 36^{\circ} 22^{\prime} 42.4^{\prime \prime} \mathrm{E}: 116^{\circ} 40^{\prime} 58.4^{\prime \prime}$ & Cultivar Xiangling & ++++ & Fruit \\
\hline 4 & SL-31 & $\begin{array}{l}\text { Yanping village, Sanchahe town, } \\
\text { Shangluo city, Shaanxi province }\end{array}$ & $\mathrm{N}: 33^{\circ} 58^{\prime} 05.7^{\prime \prime} \mathrm{E}: 109^{\circ} 42^{\prime} 11.1^{\prime \prime}$ & Cultivar Liaohe & ++ & Fruit \\
\hline 5 & ZZ-27 & $\begin{array}{l}\text { Shuitun village, Yicheng district, } \\
\text { Zaozhuang city, Shandong province }\end{array}$ & $\mathrm{N}: 34^{\circ} 46^{\prime} 25.8^{\prime \prime} \mathrm{E}: 117^{\circ} 39^{\prime} 19.9^{\prime \prime}$ & Cultivar Xiangling & +++ & Fruit \\
\hline 6 & SL-34 & $\begin{array}{l}\text { Kanghe village, Sanchahe town, } \\
\text { Shangluo city, Shaanxi province }\end{array}$ & $\mathrm{N}: 33^{\circ} 51^{\prime} 10.5^{\prime \prime} \mathrm{E}: 109^{\circ} 41^{\prime} 59.1^{\prime \prime}$ & Cultivar Liaohe & ++ & Fruit \\
\hline 7 & YT-172 & $\begin{array}{l}\text { Zaoyuan village, Miaohou town, } \\
\text { Qixia city, Shandong province }\end{array}$ & $\mathrm{N}: 37^{\circ} 20^{\prime} 24.8^{\prime \prime} \mathrm{E}: 121^{\circ} 03^{\prime} 57.4^{\prime \prime}$ & Unknown & +++ & Fruit \\
\hline 8 & SL-30 & $\begin{array}{l}\text { Shanghe village, Chenyuan town, } \\
\text { Shangluo city, Shaanxi province }\end{array}$ & $\mathrm{N}: 33^{\circ} 25^{\prime} 32.5^{\prime \prime} \mathrm{E}: 109^{\circ} 08^{\prime} 47.3^{\prime \prime}$ & Cultivar Liaohe & +++ & Fruit \\
\hline 9 & SL-37 & $\begin{array}{l}\text { Chuanxing village, Yangxie town, } \\
\text { Shangluo city, Shaanxi province }\end{array}$ & $\mathrm{N}: 33^{\circ} 51^{\prime} 32^{\prime \prime} \mathrm{E}: 109^{\circ} 41^{\prime} 10.6^{\prime \prime}$ & Cultivar Liaohe & ++ & Fruit \\
\hline 10 & LZ-02 & $\begin{array}{l}\text { Lizhuang village, Shuangquan town, } \\
\text { Jinan city, Shandong province }\end{array}$ & $\mathrm{N}: 36^{\circ} 24^{\prime} 56.8^{\prime \prime} \mathrm{E}: 116^{\circ} 40^{\prime} 58.4^{\prime \prime}$ & Cultivar Xiangling & +++ & Fruit \\
\hline 11 & ZQ-29 & $\begin{array}{l}\text { Duozhuang village, Zaoyuan town, } \\
\text { Jinan city, Shandong province }\end{array}$ & $\mathrm{N}: 36^{\circ} 45^{\prime} 14.0^{\prime \prime} \mathrm{E}: 117^{\circ} 26^{\prime} 36.4^{\prime \prime}$ & Cultivar Xiangling & +++ & Fruit \\
\hline 12 & ZZ-01 & $\begin{array}{l}\text { Xiaofeng village, Xincun town, } \\
\text { Zhengzhou city, Henan province }\end{array}$ & $\mathrm{N}: 34^{\circ} 22^{\prime} 43.6^{\prime \prime} \mathrm{E}: 113^{\circ} 43^{\prime} 10.9^{\prime \prime}$ & Cultivar Zhonglin & ++ & Fruit \\
\hline 13 & HB-49 & $\begin{array}{l}\text { Sanxigou village, Chengguan town, } \\
\text { Xiangyang city, Hubei province }\end{array}$ & $\mathrm{N}: 31^{\circ} 52^{\prime} 02.1^{\prime \prime} \mathrm{E}: 111^{\circ} 15^{\prime} 04.0^{\prime \prime}$ & Cultivar Xiangling & +++ & Fruit \\
\hline
\end{tabular}

${ }^{\mathrm{z}++}$, Incidence 5 to $10 \%$; +++, incidence 10 to $30 \%$; ++++, severe with $>30 \%$ incidence (even total losses). 
The mycelial powder was dissolved in cetyltrimethylammonium bromide (CTAB) buffer (2\% [wt/vol] CTAB, $1.42 \mathrm{M} \mathrm{NaCl}$, $20 \mathrm{mM}$ EDTA, $100 \mathrm{mM}$ Tris $\mathrm{HCl}$ [pH 8.0], and $0.2 \%$ [wt/vol] $\beta$-mercaptoethanol) and then, incubated at $65^{\circ} \mathrm{C}$ for $30 \mathrm{~min}$. Genomic DNAs of all isolates were extracted in conformity to the method described by Freeman et al. (1996). The PCR amplifications were conducted with the ribosomal internal transcribed spacer (ITS), actin (ACT), glyceraldehyde-3-phosphate dehydrogenase (GAPDH), and chitin synthase (CHS-1). Four loci were amplified: ribosomal DNA region using universal primers ITS1 and ITS4 for ITS (Gardes and Bruns 1993; White et al. 1990), GAPDH gene using primers GDF-1 and GDR1 (Templeton et al. 1992), CHS-1 gene using primers CHS-79F and CHSI-354R (Carbone and Kohn 1999), and ACT gene using primers ACT-512F and ACT-783R (Carbone and Kohn 1999). Information about primer sequences, amplicon size, and PCR conditions is listed in Table 3.
The PCR reaction system was (with the total reaction volume of $25 \mu \mathrm{l})$ mixed with Taq DNA polymerase mix $(12.5 \mu \mathrm{l})$, primer-F $(1.0 \mu \mathrm{l})$, primer-R $(1.0 \mu \mathrm{l})$, genomic DNA $(2.0 \mu \mathrm{l})$, and $\mathrm{ddH}_{2} \mathrm{O}$ $(8.5 \mu \mathrm{l})$. The PCR amplification procedure consisted of 36 cycles, and information about initial denaturation, denaturation, annealing, extension, and final extension are listed in Table 3. After PCR, all of the PCR amplification products were sequenced by Shanghai Personal Biotechnology Co., Ltd. All sequences have been deposited in GenBank (Table 2).

All ITS, GAPDH, ACT, and CHS-1 sequences were compared with the sequences of the already described species in the Q-Bank (www.q-bank.eu) by blasting, and the sequences of $46 \mathrm{Col}$ letotrichum isolates were downloaded from GenBank (Table 2). Colletotrichum boninense MAFF 305972 was used as an outgroup, which was an ex-holotype culture that was isolated from Crinum asiaticum var. sinicum. The sequences of each locus were aligned

Table 2. Strains and sequences of the genus Colletotrichum used in this study

\begin{tabular}{|c|c|c|c|c|c|c|c|}
\hline \multirow[b]{2}{*}{ Species } & \multirow[b]{2}{*}{ Culture accession no. } & \multirow[b]{2}{*}{ Host } & \multirow[b]{2}{*}{ Country } & \multicolumn{4}{|c|}{ GenBank accession numbers ${ }^{x}$} \\
\hline & & & & ITS & GAPDH & ACT & CHS-1 \\
\hline Colletotrichum aenigma $^{\mathrm{y}}$ & ICMP 18608 & Persea americana & Israel & JX010244 & JX010044 & JX009443 & JX009774 \\
\hline Colletotrichum alatae & CBS 304.67 & Dioscorea alata & India & JX010190 & JX009990 & JX009471 & JX009837 \\
\hline $\begin{array}{l}\text { Colletotrichum } \\
\text { aeschynomenes }\end{array}$ & ICMP 17673 & Aeschynomene virginica & U.S.A. & JX010176 & JX009930 & JX009483 & JX009799 \\
\hline Colletotrichum alienum & ICMP 12071 & Malus domestica & New Zealand & JX010251 & JX010028 & JX009572 & JX009882 \\
\hline Colletotrichum aotearoa & ICMP 18537 & Coprosma sp. & New Zealand & JX010205 & JX010005 & JX009564 & JX009853 \\
\hline Colletotrichum asianum & ICMP 18580 & Coffea arabica & Thailand & FJ972612 & JX010053 & JX009584 & JX009867 \\
\hline Colletotrichum boninense & MAFF 305972 & $\begin{array}{l}\text { Crinum asiaticum var. } \\
\text { sinicum }\end{array}$ & Japan & JX010292 & JX009905 & JX009583 & JX009827 \\
\hline Colletotrichum camelliae & CGMCC 3.14925 & Camellia sinensis & China & KJ955081 & KJ954782 & KJ954363 & \\
\hline $\begin{array}{l}\text { Colletotrichum } \\
\text { chengpingense }\end{array}$ & MFLUCC 15-0022 & Fragaria vesca & China & KP683152 & KP852469 & KP683093 & KP852449 \\
\hline Colletotrichum clidemiae & ICMP 18658 & Clidemia hirta & $\begin{array}{l}\text { U.S.A., } \\
\text { Hawaii }\end{array}$ & JX010265 & JX009989 & JX009537 & JX009877 \\
\hline Colletotrichum conoides & CAUG17 & Capsicum spp. & China & KP890168 & KP890162 & KP890144 & KP890156 \\
\hline Colletotrichum cordylinicola & ICMP 18579 & Cordyline fruticosa & Thailand & JX010226 & JX009975 & HM470235 & JX009864 \\
\hline Colletotrichum endophytica & MFLUCC 130418 & Pennisetum purpureum & Thailand & KC633854 & KC832854 & KF306258 & \\
\hline Colletotrichum fructicola & CFCC 51553 & Juglans regia & China & KX913950 & KX913956 & KX913947 & KX913953 \\
\hline $\begin{array}{l}\text { Colletotrichum } \\
\text { gloeosporioides }\end{array}$ & ICMP 17821 & Citrus sinensis & Italy & JX010152 & JX010056 & JX009531 & JX009818 \\
\hline $\begin{array}{l}\text { Colletotrichum } \\
\text { gloeosporioides }\end{array}$ & ICMP 18738 & Carya illinoinensis & Australia & JX010151 & JX009976 & JX009542 & JX009797 \\
\hline $\begin{array}{l}\text { Colletotrichum } \\
\text { gloeosporioides }\end{array}$ & ICMP 12939 & Citrus sp. & New Zealand & JX010149 & JX009931 & JX009462 & JX009747 \\
\hline $\begin{array}{l}\text { Colletotrichum } \\
\text { gloeosporioides }\end{array}$ & ICMP 12066 & Ficus sp. & New Zealand & JX010158 & JX009955 & JX009550 & JX009888 \\
\hline $\begin{array}{l}\text { Colletotrichum } \\
\text { gloeosporioides }\end{array}$ & ICMP 18730 & Citrus sp. & New Zealand & JX010157 & JX009981 & JX009548 & JX009861 \\
\hline $\begin{array}{l}\text { Colletotrichum } \\
\text { gloeosporioides }\end{array}$ & ICMP 12938 & Citrus sinensis & New Zealand & JX010147 & JX009935 & JX009560 & JX009746 \\
\hline $\begin{array}{l}\text { Colletotrichum } \\
\text { gloeosporioides }\end{array}$ & ICMP 18694 & Mangifera indica & South Africa & JX010155 & JX009980 & JX009481 & JX009796 \\
\hline $\begin{array}{l}\text { Colletotrichum } \\
\text { gloeosporioides }\end{array}$ & ICMP 18678 & Pueraria lobata & U.S.A. & JX010150 & JX010013 & JX009502 & JX009790 \\
\hline $\begin{array}{l}\text { Colletotrichum } \\
\text { gloeosporioides }\end{array}$ & ICMP 18695 & Citrus sp. & U.S.A. & JX010153 & JX009979 & JX009494 & JX009779 \\
\hline $\begin{array}{l}\text { Colletotrichum } \\
\text { gloeosporioides }\end{array}$ & ICMP 18697 & Vitis vinifera & U.S.A. & JX010154 & JX009987 & JX009557 & JX009780 \\
\hline $\begin{array}{l}\text { Colletotrichum } \\
\text { gloeosporioides }\end{array}$ & ICMP 19121 & Citrus limon & Italy & JX010148 & JX010054 & JX009558 & JX009903 \\
\hline $\begin{array}{l}\text { Colletotrichum } \\
\text { gloeosporioides }\end{array}$ & $\begin{array}{l}\mathrm{SMX}-42 \mathrm{H}=\mathrm{CFCC} \\
52827^{\mathrm{z}}\end{array}$ & Juglans regia & China & MF554884 & MF554870 & MF554844 & MF554853 \\
\hline $\begin{array}{l}\text { Colletotrichum } \\
\text { gloeosporioides }\end{array}$ & TS-09 = CFCC 52838 & Juglans regia & China & MF554878 & MF554872 & MF554846 & MF554855 \\
\hline $\begin{array}{l}\text { Colletotrichum } \\
\text { gloeosporioides }\end{array}$ & $\begin{array}{l}\text { SQ-141 = CFCC } \\
52833^{z}\end{array}$ & Juglans regia & China & MF554883 & MF554871 & MF554845 & MF554854 \\
\hline & & & & & & (Continued o & n next page) \\
\hline
\end{tabular}

x ACT, actin; CHS-1, chitin synthase; GAPDH, glyceraldehyde-3-phosphate dehydrogenase; ITS, internal transcribed spacer.

y Ex-type strains or authentic cultures are in bold.

${ }^{\mathrm{z}}$ Strains collected in this study. 
using MEGA 7.0, the gaps were considered as missing data, and the alignments were adjusted manually for maximum alignment and maximum sequence similarity. Four genes per region were concatenated in an order of "ITS-GAPDH-ACT-CHS-1" using Fasta alignment joiner software (http://users-birc.au.dk/palle/php/fabox/ alignment_joiner.php). Phylogenetic analyses were performed with the concatenated sequence dataset using MEGA 7.0 software (Kumar et al. 2016), and two multilocus phylogenetic trees were generated with neighbor-joining method or maximum parsimony method. The phylogenetic trees were drawn to scale, and the optimal tree with the sum of branch length was measured according to the number of substitutions per site to evaluate the relative stability of the branches.

Pathogenicity and virulence in leaves and fruits. Pathogenicity experiments were conducted at the experimental station of the Research Center for the Prevention and Control of Invasive Forest Pests of Shandong Province. Healthy fruits (cultivar Xiangling, 1 month old) and leaves (fully expanded) were inoculated in vitro with plugs $(\varnothing=5 \mathrm{~mm})$ of isolates cultured for 5 days. Thirteen isolates were used (Table 2). In total, 280 fruits and 168 leaves were rinsed with running tap water for $60 \mathrm{~s}$, surface sterilized with $70 \%$ ethanol, and rinsed with sterile distilled water three times. All of the fruits and leaves were punctured with a red-hot needle $(\varnothing=0.5 \mathrm{~mm})$ on the surface. The leaf was inoculated with two hyphal plugs, and the fruit was inoculated with one hyphal plug; the needle-wounded leaves and fruits were inoculated with blank agar plug as a control. Each isolate was inoculated to 20 fruits and 12 leaves; an additional 20 fruits and 12 leaves were treated with blank agar plugs as controls. All treatments and controls were placed into sterile tissue culture bottles $(\varnothing=$ $92 \mathrm{~mm}, h=274 \mathrm{~mm}, v=690 \mathrm{ml}$ ) containing two layers of wet paper towels to keep them moist at $28^{\circ} \mathrm{C}$ under a 12-h light/dark cycle. Anthracnose symptoms were evaluated at the seventh day after inoculation. The fungus was reisolated from symptomatic lesions using the aforementioned method. The morphological characters

Table 2. (Continued from previous page)

\begin{tabular}{|c|c|c|c|c|c|c|c|}
\hline \multirow[b]{2}{*}{ Species } & \multirow[b]{2}{*}{ Culture accession no. } & \multirow[b]{2}{*}{ Host } & \multirow[b]{2}{*}{ Country } & \multicolumn{4}{|c|}{ GenBank accession numbers ${ }^{x}$} \\
\hline & & & & ITS & GAPDH & ACT & CHS-1 \\
\hline $\begin{array}{l}\text { Colletotrichum } \\
\text { gloeosporioides }\end{array}$ & $\mathrm{SL}-31=\mathrm{CFCC} 52830^{\mathrm{z}}$ & Juglans regia & China & MF554879 & MF554867 & MF554840 & MF554857 \\
\hline $\begin{array}{l}\text { Colletotrichum } \\
\text { gloeosporioides }\end{array}$ & $\mathrm{ZZ}-27=\mathrm{CFCC} 52837^{\mathrm{z}}$ & Juglans regia & China & MF554887 & MF554876 & MF554850 & MF554863 \\
\hline $\begin{array}{l}\text { Colletotrichum } \\
\text { gloeosporioides }\end{array}$ & SL-34 = CFCC 52831 & Juglans regia & China & MF554890 & MF554868 & MF554842 & MF554858 \\
\hline $\begin{array}{l}\text { Colletotrichum } \\
\text { gloeosporioides }\end{array}$ & $\begin{array}{l}\mathrm{YT}-172=\mathrm{CFCC} \\
52836^{\mathrm{z}}\end{array}$ & Juglans regia & China & MF554889 & MF554874 & MF554848 & MF554861 \\
\hline $\begin{array}{l}\text { Colletotrichum } \\
\text { gloeosporioides }\end{array}$ & SL-30 = CFCC 52829c & Juglans regia & China & MF554880 & MF554866 & MF554841 & MF554856 \\
\hline $\begin{array}{l}\text { Colletotrichum } \\
\text { gloeosporioides }\end{array}$ & SL-37 $=$ CFCC $52832^{z}$ & Juglans regia & China & KY302642 & KY302639 & KY302631 & KY302635 \\
\hline $\begin{array}{l}\text { Colletotrichum } \\
\text { gloeosporioides }\end{array}$ & $\mathrm{LZ}-02=\mathrm{CFCC} 52834^{\mathrm{z}}$ & Juglans regia & China & MF554881 & MF554865 & MF554839 & MF554852 \\
\hline $\begin{array}{l}\text { Colletotrichum } \\
\text { gloeosporioides }\end{array}$ & ZQ-29 = CFCC 52824" & Juglans regia & China & KY302643 & KY302638 & KY302630 & KY302634 \\
\hline $\begin{array}{l}\text { Colletotrichum } \\
\text { gloeosporioides }\end{array}$ & $\mathrm{ZZ}-01^{\mathrm{Z}}$ & Juglans regia & China & MF554886 & MF554875 & MF554849 & MF554862 \\
\hline $\begin{array}{l}\text { Colletotrichum } \\
\text { gloeosporioides }\end{array}$ & $\mathrm{HB}-49=\mathrm{CFCC} 52826^{\mathrm{z}}$ & Juglans regia & China & MF554882 & MF554864 & MF554838 & MF554851 \\
\hline Colletotrichum grevilleae & CBS 132879 & Grevillea sp. & Italy & KC297078 & KC297010 & KC296941 & KC296987 \\
\hline Colletotrichum grossum & CAUG7 & Capsicum spp. & China & KP890165 & KP890159 & KP890141 & KP890153 \\
\hline Colletotrichum hebeiense & MFLUCC 13-0726 & Vitis vinifera & China & KF156863 & KF377495 & KF377532 & KF289008 \\
\hline Colletotrichum henanense & CGMCC 3.17354 & Camellia sinensis & China & KJ955109 & KJ954810 & & KM023257 \\
\hline Colletotrichum horii & NBRC7478 & Diospyros kaki & Japan & GQ329690 & GQ329681 & JX009438 & JX009752 \\
\hline Colletotrichum jiangxiense & CGMCC 3.17363 & Camellia sinensis & China & KJ955201 & KJ954902 & KJ954471 & \\
\hline Colletotrichum kahawae & ICMP17816 & Coffea arabica & Kenya & JX010231 & JX010012 & JX009452 & JX009813 \\
\hline Colletotrichum musae & ICMP 116870 & Musa sp. & U.S.A. & JX010146 & JX010050 & JX009433 & JX009896 \\
\hline Colletotrichum nupharicola & CBS470.96 & $\begin{array}{l}\text { Nuphar lutea subsp. } \\
\text { polysepala }\end{array}$ & U.S.A. & JX010187 & JX009972 & JX009437 & JX009835 \\
\hline Colletotrichum proteae & CBS 132882 & Protea sp. & South Africa & KC297079 & КС297009 & KC296940 & KC296986 \\
\hline Colletotrichum psidii & CBS 145.29 & Psidium sp. & Italy & JX010219 & JX009967 & JX009515 & JX009901 \\
\hline $\begin{array}{l}\text { Colletotrichum } \\
\text { queenslandicum }\end{array}$ & ICMP 1778 & Carica papaya & Australia & JX010276 & JX009934 & JX009447 & JX009899 \\
\hline Colletotrichum salsolae & ICMP 19051 & Salsola tragus & Hungary & JX010242 & JX009916 & JX009562 & JX009863 \\
\hline Colletotrichum siamense & CFCC 51940 & Juglans regia & China & KY242352 & KY242347 & KY242336 & KY242342 \\
\hline Colletotrichum syzygicola & MFLUCC 10-0624 & Syzygium samarangense & Thailand & NR152278 & KF242156 & KF157801 & \\
\hline $\begin{array}{l}\text { Colletotrichum } \\
\text { theobromicola }\end{array}$ & CBS 124945 & Theobroma cacao & Panama & JX010294 & JX010006 & JX009444 & JX009869 \\
\hline Colletotrichum ti & ICMP 4832 & Cordyline sp. & New Zealand & JX010269 & JX009952 & JX009520 & JX009898 \\
\hline Colletotrichum tropicale & ICMP 18653 & Theobroma cacao & Panama & JX010264 & JX010007 & JX009489 & JX009870 \\
\hline Colletotrichum viniferum & GZAAS 5.08601 & Vitis vinfera 'Shuijing' & China & JN412804 & JN412798 & JN412795 & \\
\hline Colletotrichum wuxiense & CGMCC 3.17894 & Camellia sinensis & China & KU251591 & KU252045 & KU251672 & KU251939 \\
\hline $\begin{array}{l}\text { Colletotrichum } \\
\text { xanthorrhoeae }\end{array}$ & BRIP 45094 & Xanthorrhoea preissii & Australia & JX010261 & JX009927 & JX009478 & JX009823 \\
\hline
\end{tabular}


of the reisolates, such as colony, acervuli, conidia, appressoria, conidiophores, and conidiogenous cells, were compared with those of the inoculated isolates to complete Koch's postulates.

The lesion sizes and areas on fruits or leaves were measured at the 10th day after inoculation to evaluate virulence. The virulence of the isolates was compared using one-way analysis of variance, and means were compared by Tukey's honestly significant difference (HSD) test at the $1 \%$ significance level using IBM SPSS Statistics 20 software.

In vitro sensitivity of isolates to four fungicides. The inhibitive activities of tebuconazole, difenoconazole, flusilazole, and carbendazim to the isolates were estimated using a mycelium growth rate method in the laboratory.

Tebuconazole ( $97 \%$ a.i.; provided by Jiangsu Changlong Agrochemical Co., Ltd.) and difenoconazole ( $95.8 \%$ a.i.; provided by Qingdao Hansen Biologic Science Co., Ltd.) were dissolved in acetone; flusilazole (92\% a.i.) and carbendazim (97.5\% a.i.; provided by Qingdao Hansen Biologic Science Co., Ltd.) were dissolved in cyclohexanone and $1 \%(\mathrm{wt} / \mathrm{wt})$ hydrochloric acid, respectively. The concentration of all solutions was $10,000 \mu \mathrm{g} / \mathrm{ml}$, and they were stored at $4^{\circ} \mathrm{C}$.

Four fungicides were added to autoclaved PDA cooled to ca. $50^{\circ} \mathrm{C}$. PDA media were amended to result in $0.25,0.5,1.0,2.0$, and 4.0 $\mu \mathrm{g} / \mathrm{ml}$ a.i. of tebuconazole, flusilazole, or difenoconazole and $0.125,0.25,0.5,1.0$, and $2.0 \mu \mathrm{g} / \mathrm{ml}$ a.i. of carbendazim. PDA medium without fungicide was used as control. Approximately $15 \mathrm{ml}$ of PDA medium was decanted to each plate $(\varnothing=90 \mathrm{~mm})$. The isolates were cultured on PDA without fungicides at $28^{\circ} \mathrm{C}$ for 5 days, and the hyphae were cut into plugs $(\varnothing=5 \mathrm{~mm})$ with a cork borer. The plugs were placed at the center of PDA plates.

Additionally, one plug per plate was cultured at $28^{\circ} \mathrm{C}$ for 3 days. Each treatment and control had four replicates, and the experiments were performed twice. The colony diameters were measured in a cross pattern. The original plug diameter was subtracted and mean of the colony diameters was calculated. All data were analyzed using IBM SPSS Statistics 20 software, and concentration for $50 \%$ of maximal effect $\left(\mathrm{EC}_{50}\right)$ values were estimated by the probit analysis. The frequency distribution of $\mathrm{EC}_{50}$ of the 13 isolates was plotted using PROC FREQ and tested for normality (Fan et al. 2016).

\section{Results}

Description of symptoms in the field. In major walnut production areas, walnut anthracnose disease mainly damaged leaves and fruits. When the leaves were infected, the spots were nearly round or irregular, water soaked, and brown to dark brown. The spots expanded along the veins and formed long strip lesions. In a later stage, the older lesions became necrotic and perforated, and this resulted in early defoliation (Fig. 1A). When the fruits were infected, some subcircular or irregular spots appeared in the initial stage. The spots were water soaked, sunken, and brown to black (Fig. 1B). Some spots enlarged and merged into large necrotic areas. In the necrotic areas, some acervuli were in concentric rings and oozed gelatinous pink conidial masses (Fig. 1C). When the disease was serious, multiple spots merged and expanded to the whole fruit (Fig. 1D), and the pathogen reached the immature endocarp (nut shell). The fruits failed to
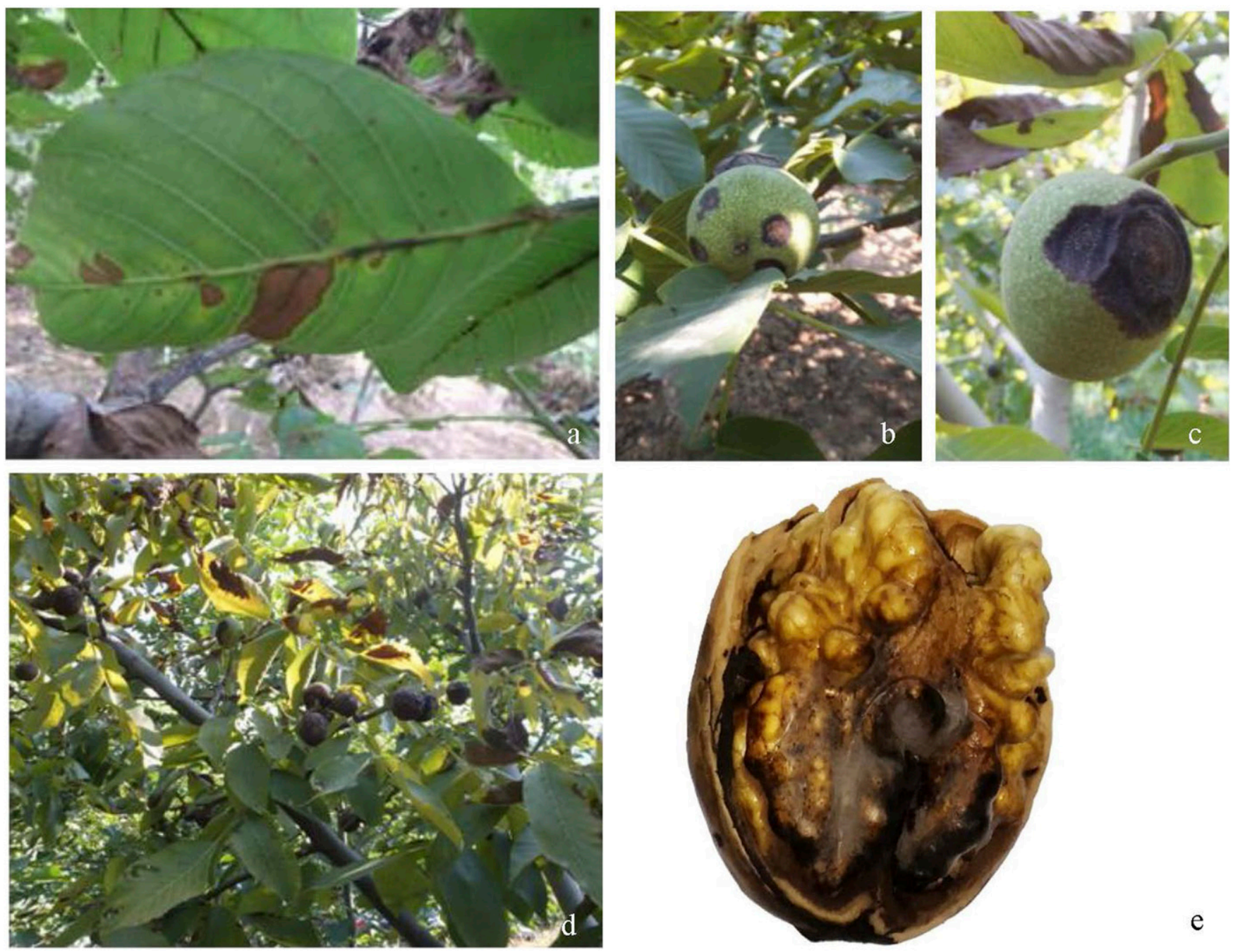

Fig. 1. Disease symptoms of walnut anthracnose on fruits and leaves of walnuts in the field. $a$, Disease symptoms on walnut leaves. $b$ to $d$, Disease symptoms on walnut fruits. e, Disease symptoms on walnut kernels. 
develop normally; most fruits dropped prematurely, and the kernels (nutmeat) were inedible (Fig. 1E). The degree of the severity of walnut pericarp was in substantial agreement with walnut kernels. With the walnut pericarp spot expansion, the risk of damage to walnut kernels increased. At the initial infection period, the spots were only in walnut pericarp, not in kernels, at this time, and the walnut kernels quality was not influenced by walnut anthracnose. When the walnut pericarp spot area was up to one-fourth of the whole fruit, the kernels were infected, and some spots were in kernels. At this point, the quality and quantity of the kernels were reduced (Fig. 2).

Isolate collection. The incidence was different in the 13 orchards, the highest incidence was in orchards 2 and 3 , and the walnut variety was Xiangling (Table 1). A total of 59 isolates were obtained from diseased fruits and leaves. In orchard 7, the genera Colletotrichum and Fusarium were isolated. The genera Colletotrichum and Alternaria were isolated in orchards 4, 6, and 8, and the genera Colletotrichum and Xanthomonas were in orchards 10 and 11 . One Colletotrichum isolate was selected to represent an orchard (Table 1), and 13 isolates were preserved.

Morphological characteristics. On PDA, aerial mycelium was dense and cottony; the colonies were milky, pale gray to medium gray toward the center, in reverse, gray, and olivaceous gray to blue gray at the center, with sporadic dark gray flecks on the edge (Fig. 3A to $\mathrm{C}$ ). Colonies were with the entire margin, and orange conidial masses were visible in acervuli. Sexual morph was absent. Asexual morph was present on PDA. Hypha was hyaline to medium brown, smooth, septate, and branched. Acervuli were observed (Fig. 3D). Setae were not observed. Conidiophores were hyaline, smooth walled, and sometimes branched. Conidiogenous cells were hyaline, smooth, and cylindrical, often with a septum (Fig. 3G and $\mathrm{H}$ ).
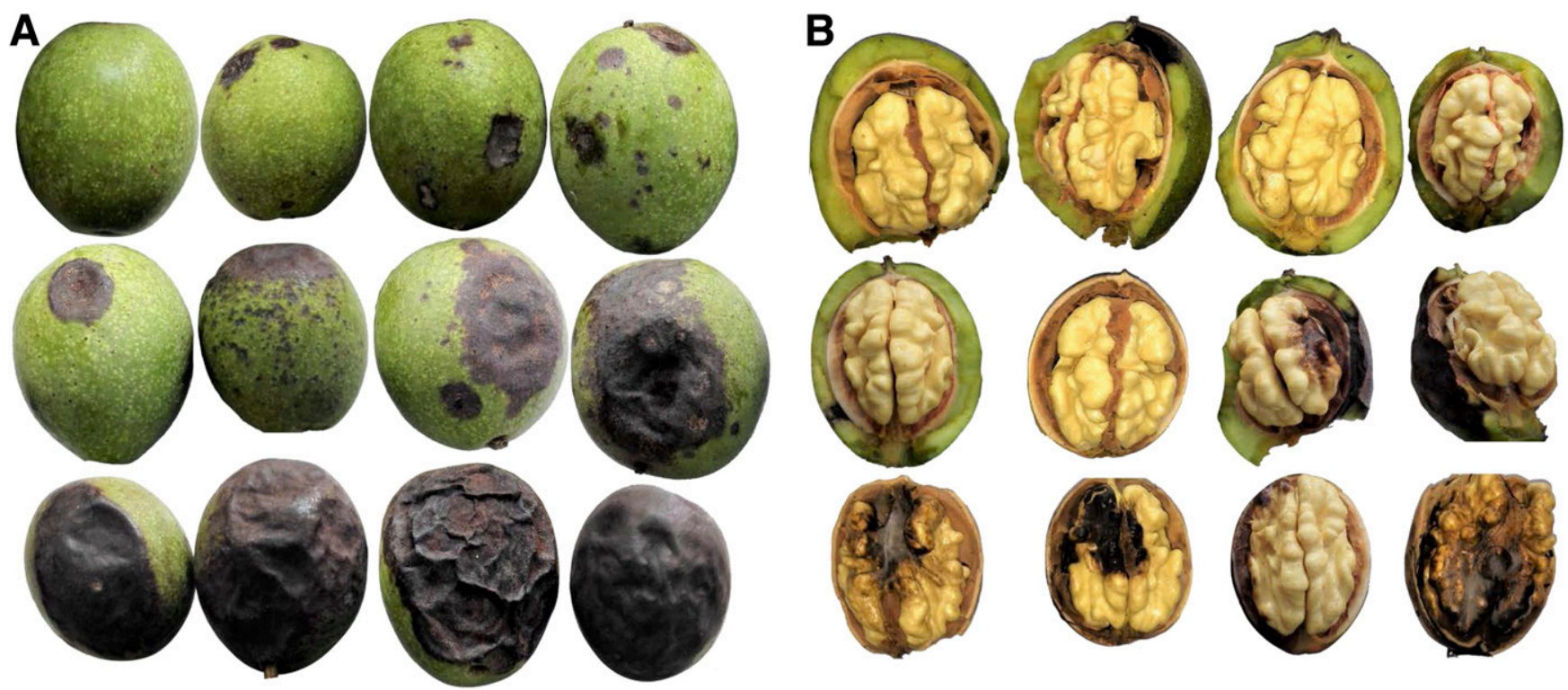

Fig. 2. The various degrees of the severity of inner and outer symptoms of walnut anthracnose on fruit. A, The various severity degrees of walnut anthracnose on pericarp. B, The corresponding various severity degrees on walnut kernels.
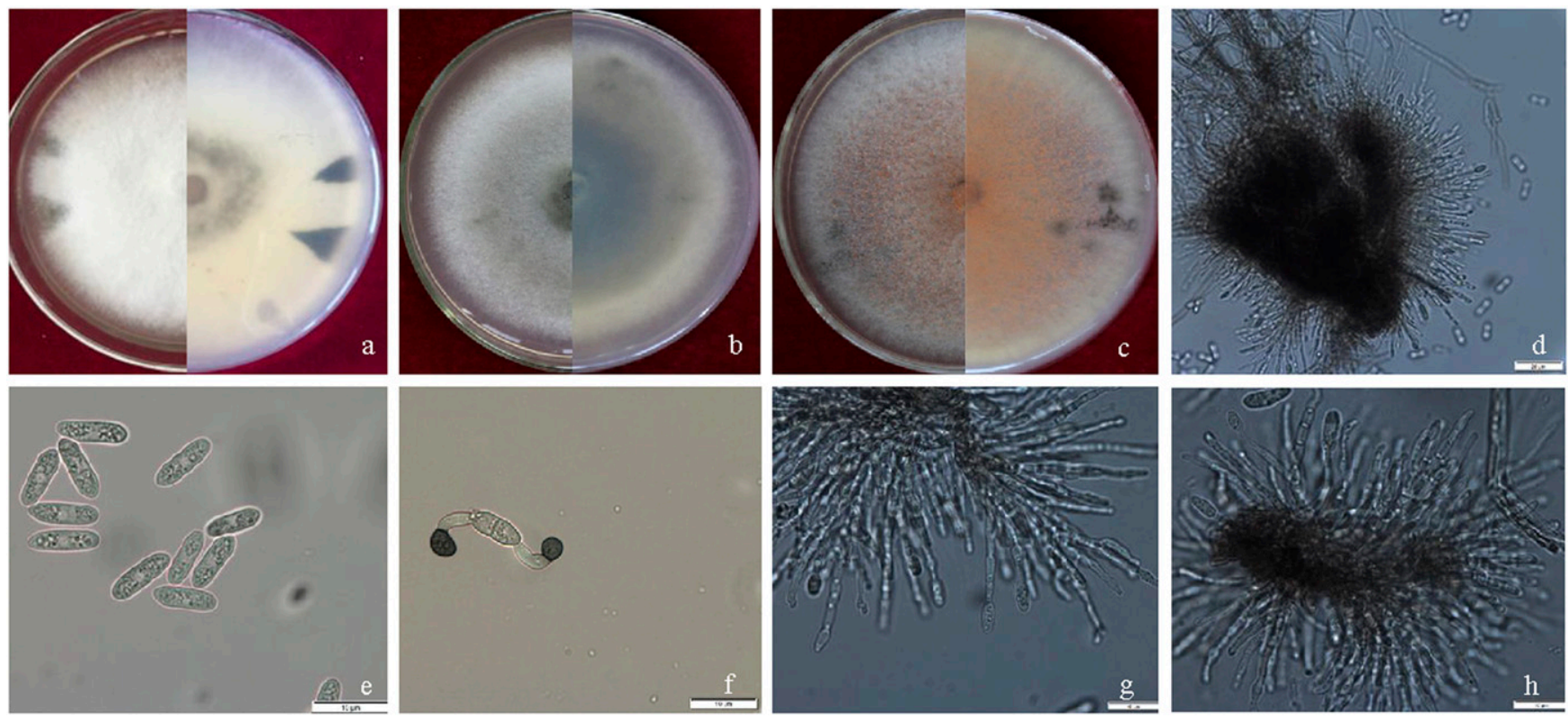

Fig. 3. The morphological characteristics of Colletotrichum gloeosporioides sensu stricto isolated from walnut anthracnose fruits on potato dextrose agar. a to $\mathrm{c}$, Cultural characters. a, Isolate SQ-141. b, Isolate SL-31. c, Isolate LZ-02. d, Acervulus. Scale bar $=20 \mu \mathrm{m}$. e, Conidia. Scale bar $=10 \mu \mathrm{m}$. f, Appressoria. Scale bar $=10 \mu \mathrm{m}$. g, Conidiophores and conidiogenous cells. Scale bar $=10 \mu \mathrm{m}$. h, Acervulus, conidiophores, and conidiogenous cells. Scale bar $=10 \mu \mathrm{m}$. 
Conidia were straight and mostly cylindrical with broadly rounded ends that were sometimes slightly and gradually acute to the end (Fig. $3 \mathrm{E})$. The size was $(14.8-) 16.7-17.3(-19.5) \times(4.3-) 5.0-5.3$ $(-6.1) \mu \mathrm{m}(\overline{\mathrm{x}}=16.9 \pm 1.0 \times 5.2 \pm 0.4, n=51)$, and L/W = 3.3. Appressoria were simple or in a small group, subglobose or ellipsoid, and rarely irregular (Fig. 3F). The size was $(5.2-) 6.7-7.6(-8.9)$ $\times(2.7-) 5.0-5.9(-7.1) \mu \mathrm{m}(\overline{\mathrm{x}}=7.2 \pm 1.1 \times 5.4 \pm 1.0, n=26)$, and
$\mathrm{L} / \mathrm{W}=1.3$. Consequently, the isolates were identified as $C$. gloeosporioides.

Phylogenetic analyses. Using the Blast option in the Q-Bank, all ITS, GAPDH, ACT, and CHS-1 sequences were compared with the sequences of the known species.

Compared with the sequences of $C$. gloeosporioides sensu stricto (s.s.) isolates ICMP 17821 and ICMP 12939, the similarity of ITS

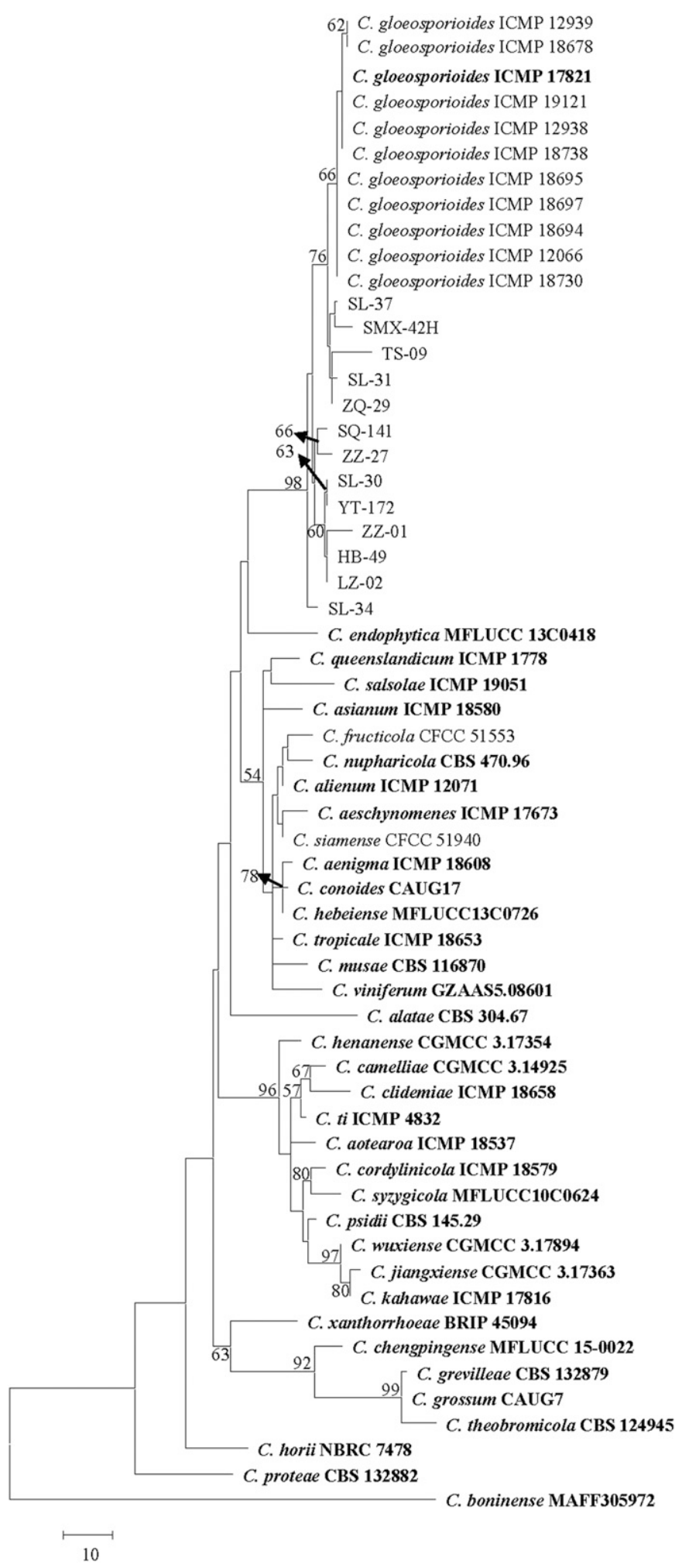

Fig. 4. Phylogenetic tree of isolates of walnut anthracnose, Colletotrichum gloeosporioides sensu stricto, with allied taxa calculated with concatenated sequence data of internal transcribed spacer, glyceraldehyde-3-phosphate dehydrogenase, actin, and chitin synthase using maximum parsimony method (1,000 bootstrap replicates; bootstrap values indicated at nodes). Colletotrichum boninense MAFF 305972 is the outgroup. The scale bar indicates the number of expected changes per site. The isolates in bold are ex-types. 
was from 99.3 to $100 \%$; the CHS-1 sequences of all isolates showed 99.2 to $100 \%$ similarity. The similarity of GAPDH was from 89.9 to 98.6\%, and the ACT sequences of isolates SL-30, LZ-02, SQ-141, ZZ-27, YT-172, SL-31, HB-49, SL-37, SL-34, SMX-42H, and ZQ-29 showed 100 and $99.6 \%$ similarity with $C$. gloeosporioides s.s. isolates ICMP 17821 and ICMP 12939, respectively (Supplementary Table S1).

To compare with the sequences of 46 isolates downloaded from GenBank, ITS, GAPDH, ACT, and CHS-1 of all isolates were concatenated with the Fasta alignment joiner software. The aligned sequence was from 98.0 to $99.5 \%$ homologous to ex-type C. gloeosporioides s.s. ICMP 17821. The multilocus phylogenetic trees were generated using neighbor-joining and maximum parsimony methods. There were a total of 1,061 sites in the final dataset, and conserved sites, variable sites, parsimony informative sites, and singleton sites were $715,312,163$, and 140 , respectively. In the maximum parsimony phylogenetic tree, the tree length was 465 , the consistency index was 0.56 , and the retention index was 0.84 . The composite indices were 0.57 for all sites and 0.47 for parsimonyinformative sites. The isolates tested were in the same cluster with C. gloeosporioides s.s. with $98 \%$ bootstrap support (Fig. 4). In the neighbor-joining phylogenetic tree, the sum of the branch length was 0.57. All 13 isolates studied were clustered with C. gloeosporioides s.s., including its ex-type with $100 \%$ bootstrap support (Supplementary Fig. S1).

The multilocus phylogenetic analyses of four genes as well as morphological characters, including colony, conidia, appressoria, conidiophores, and conidiogenous cells, demonstrated that all of the isolates were $C$. gloeosporioides s.s.

Pathogenicity and virulence to leaves and fruits. Walnut fruits and leaves were inoculated with 13 isolates. The infection occurred at the inoculation sites on leaves or fruits (Supplementary Fig. S2A to $\mathrm{M}$ ), and symptoms resembled the anthracnose disease symptoms in the field (Fig. 1). The fruits and leaves in the controls had no symptoms 7 days after inoculation with blank agar plugs (Supplementary Fig. S2N). The typical symptom appeared as a roughly circular or irregular spot, and the infections were water soaked, sunken, and brown to black. The black lesions expanded and turned into necrotic areas. The fungus was reisolated from lesions using the aforementioned methods. Koch's postulates were completed, and the results indicated that all 13 isolates obtained were the walnut anthracnose pathogen.

There were significant differences $(P<0.01)$ among the 13 isolates that caused anthracnose disease on walnut leaves or fruits. The lesion areas on leaves were from $0.44 \pm 0.03$ to $1.42 \pm 0.21 \mathrm{~cm}^{2}$. Isolate ZQ29 showed the highest virulence, whereas isolate YT-172 was the weakest in pathogenicity to walnut leaves. At the $P<0.01$ level, all 13 isolates were divided into seven groups (Fig. 5). Based on the fruit lesion size, the isolate SQ-141 was the most virulent, and the lesion size was $2.53 \pm 0.25 \times 1.97 \pm 0.25 \mathrm{~cm}$. Isolates LZ-02, SL-34, and HB-49 showed the weakest virulence, and the lesion sizes were $0.73 \pm 0.05 \times 0.63 \pm 0.05,0.77 \pm 0.11 \times 0.67 \pm 0.05$, and $0.77 \pm$ $0.05 \times 0.67 \pm 0.05 \mathrm{~cm}$, respectively. There were no significant differences $(P<0.01)$. The 13 isolates were distributed into five groups (Fig. 5).

The disease lesion on leaves and fruits inoculated with the same isolate showed considerable differences. The 13 isolates were divided into three groups by comparing the virulence to walnut leaves and fruits. In group 1 , the virulence to walnut fruits was higher than that to leaves, and nine isolates $(69.2 \%)$ were in group 1 . In group 2 , there was no difference in pathogenicity, including isolates LZ-02 and ZQ-29. In group 3, the virulence of isolates to walnut leaves was higher, and isolates ZZ-01 and HB-49 were clustered in group 3 .

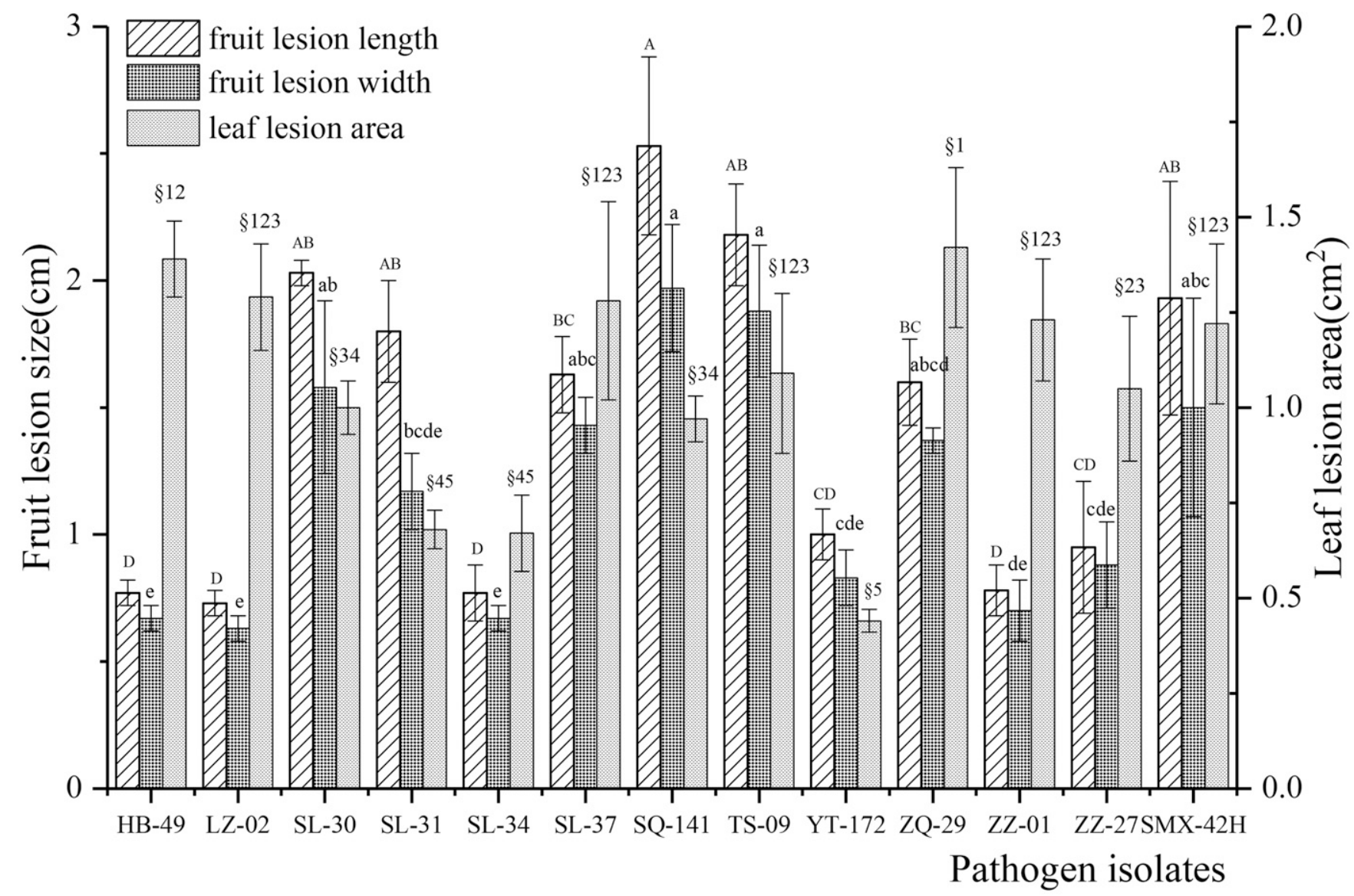

Fig. 5. Results of inoculations with Colletotrichum gloeosporioides sensu stricto (s.s.): mean fruit lesion size (centimeters) and leaves lesion area (centimeters ${ }^{2}$ ) caused by $C$. gloeosporioides s.s. isolates associated with walnut anthracnose. Bars above columns are the standard errors. Bars with the same pattern and letter (symbols) do not show significant differences according to Tukey's honestly significant difference (HSD) test $(P<0.01)$. 
In vitro sensitivity of $C$. gloeosporioides s.s. isolates to four fungicides. Four fungicides inhibited the growth of fungal mycelium. Tebuconazole, difenoconazole, flusilazole, and carbendazim $\mathrm{EC}_{50}$ values were $6.5 \pm 6.9,1.5 \pm 0.6,0.9 \pm 0.4$, and $0.1 \pm$ $0.05 \mu \mathrm{g} / \mathrm{ml}$, respectively (Table 4). C. gloeosporioides s.s. was more sensitive to difenoconazole, flusilazole, and carbendazim than to tebuconazole $(P<0.01)$. The toxicities of carbendazim, flusilazole, and difenoconazole to $C$. gloeosporioides s.s. were not different $(P<0.01)$.

The result confirmed that the resistance ratios of all of the isolates to four fungicides were different (Fig. 6). The sensitivities to carbendazim and tebuconazole were significantly different among all isolates. The resistance ratios to carbendazim were from 1 to 87.33 ; isolate HB-49 was the most sensitive one, whereas isolate SL-31 was the least sensitive to carbendazim. The resistance ratios to tebuconazole were from 1 to 51.59. Isolate SL-31 was the most sensitive one, and isolate TS-09 was the least sensitive one of all isolates. The sensitivities to difenoconazole and flusilazole were largely consistent among all isolates, and the resistance ratios were from 1 to 4.55 and 7 , respectively.

There was a significant difference in resistance ratio of carbendazim among the isolates. Therefore, difenoconazole and flusilazole could be used for disease control.

\section{Discussion}

Tode was the first one to observe the genus Colletotrichum in 1790, and Corda (1831) legitimately described it in 1831. Since 2009, Cai et al. (2009) have proposed a Colletotrichum systematics approach based on a multigene phylogeny, comparing the isolates under study with type specimens. A clearly defined phylogenetic lineage should be combined with decipherable polyphasic characters, including morphology, physiology, pathogenicity, cultural characteristics, and secondary metabolites. The taxonomy of the genus $\mathrm{Col}$ letotrichum has been significantly changed, and it has gone through numerous revisions, with the addition, typification, and synonymy of many species. Some new species were introduced; some species were segregated, and some species were abolished. As of 2019, there are 213 accepted species in the genus Colletotrichum (Dar et al. 2018; de Silva et al. 2019; Douanla-Meli and Unger 2017; Fu et al. 2019; Gan et al. 2019; Jayawardena et al. 2016, 2017; Lee and Jung 2018; Marin-Felix et al. 2017; Sharma et al. 2017; Sun et al. 2019; $\mathrm{Xu}$ et al. 2018). Most members of the genus Colletotrichum are important plant pathogens. Colletotrichum spp. may cause walnut anthracnose. Before 2015, the pathogen was identified as $C$. gloeosporioides based on morphologic characters or ITS data analysis in China (Qu et al. 2011; Xiao et al. 2010; Zhu et al. 2014). C. gloeosporioides is a species complex and includes 38 closely related species (Jayawardena et al. 2016; Marin-Felix et al. 2017; Weir et al. 2012). These reports failed to determine the species to which the pathogens belonged in C. gloeosporioides s.l. Subtle differences in colony morphology exist among the sibling species, whereas the colonies of different isolates of the same species are morphologically different. Different Colletotrichum species could infect the same host, and the same species could infect different hosts. Several mycologists who worked on Colletotrichum taxonomy opined that the taxonomy system of the genus Colletotrichum based on morphological characteristics, host range, and ITS data was confusing and that identification results were problematic (Than et al. 2008; Weir et al. 2012; Yang et al. 2009). Proper identification of the pathogen is the basis for developing effective management strategies. Therefore, it is very important to accurately distinguish the species from each other. In this paper, by using multigene phylogeny, morphologic characters, and cultural properties, we confirmed that $C$. gloeosporioides s.s. was one of the species of the genus Colletotrichum responsible for walnut anthracnose in China.

Several Colletotrichum species have been associated with walnut anthracnose, such as $C$. siamense, $C$. fructicola, C. fioriniae, $C$. gloeosporioides s.s., C. nymphaeae, $C$. godetiae, and C. gloeosporioides s.1. (Da Lio et al. 2018; Savian et al. 2019; Wang et al. 2017, 2018; Zhu et al. 2015). It is safe to state that walnut anthracnose is a complex disease. With more and more walnut anthracnose samples collected from more walnut orchards in wider geographic areas in China, it is possible that more Colletotrichum species or new species responsible for walnut anthracnose will be determined or described. Da Lio et al. (2018) obtained C. fioriniae and C. godetiae from nuts and buds in the same orchard, and they all caused walnut anthracnose. Multiple Colletotrichum species can occur in the same orchard and from different walnut isolation sites. Whether multiple species may occur in the same walnut tissues remains

Table 4. Toxicity of four fungicides to Colletotrichum gloeosporioides sensu stricto

\begin{tabular}{lcc}
\hline Fungicides & $\mathbf{E C}_{\mathbf{5 0}} \mathbf{x}(\boldsymbol{\mu g} / \mathbf{m l})$ & $\mathbf{9 5 \%} \mathbf{C I}^{\mathbf{y}}(\boldsymbol{\mu} \mathbf{g} / \mathbf{m l})$ \\
\hline Tebuconazole & $6.5 \pm 6.9 \mathrm{~A}^{\mathrm{z}}$ & $2.3-10.6$ \\
Difenoconazole & $1.5 \pm 0.6 \mathrm{~B}$ & $1.1-1.8$ \\
Flusilazole & $0.9 \pm 0.4 \mathrm{~B}$ & $0.6-1.1$ \\
Carbendazim & $0.1 \pm 0.05 \mathrm{~B}$ & $0.05-0.11$ \\
\hline
\end{tabular}

${ }^{\mathrm{x}} \mathrm{EC}_{50}$ : concentration for $50 \%$ of maximal effect.

y $95 \%$ CI.

${ }^{\mathrm{z}}$ Means having a common letter in the same column are not significantly different according to Tukey's honestly significant difference (HSD) test $(P<0.01)$.

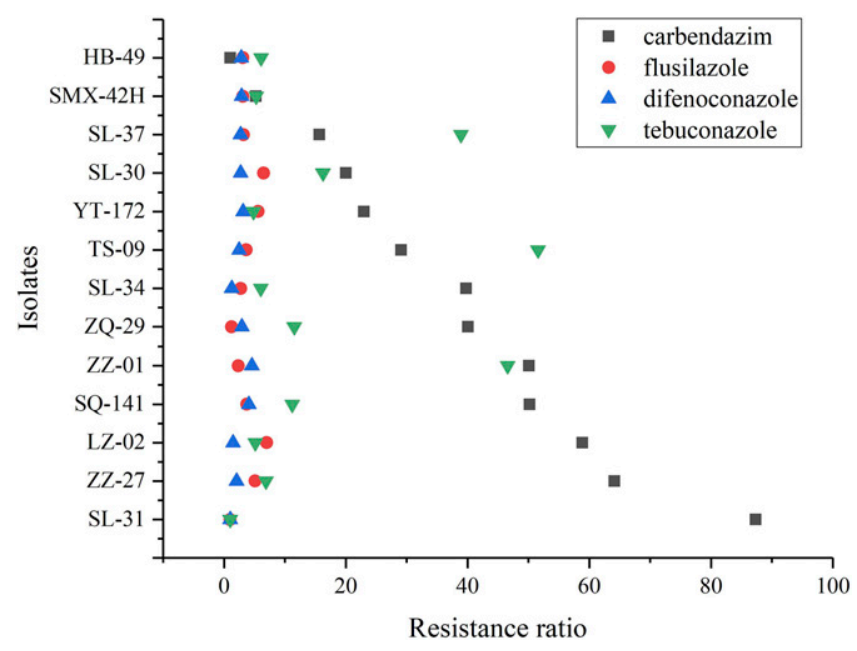

Fig. 6. The resistance ratio of Colletotrichum gloeosporioides sensu stricto isolates to four fungicides: carbendazim, flusilazole, difenoconazole, and tebuconazole.

Table 3. Primers used in this study with sequence, amplicon size, sources, and PCR conditions

\begin{tabular}{|c|c|c|c|c|c|c|c|c|c|c|c|c|c|c|}
\hline \multirow[b]{2}{*}{ Gene } & \multirow[b]{2}{*}{ Primer } & \multirow[b]{2}{*}{ Sequence } & \multirow[b]{2}{*}{ Size (bp) } & \multicolumn{2}{|c|}{$\begin{array}{c}\text { Initial } \\
\text { denaturation }\end{array}$} & \multicolumn{2}{|c|}{ Denaturation } & \multicolumn{2}{|c|}{ Annealing } & \multicolumn{2}{|c|}{ Extension } & \multicolumn{2}{|c|}{$\begin{array}{c}\text { Final } \\
\text { extension }\end{array}$} & \multirow[b]{2}{*}{ Reference } \\
\hline & & & & ${ }^{\circ} \mathrm{C}$ & $\min$ & ${ }^{\circ} \mathrm{C}$ & $\min$ & ${ }^{\circ} \mathrm{C}$ & $\min$ & ${ }^{\circ} \mathrm{C}$ & $\min$ & ${ }^{\circ} \mathrm{C}$ & $\min$ & \\
\hline $\begin{array}{l}\text { ITS }^{\mathrm{z}} \\
\text { ITS }^{2}\end{array}$ & $\begin{array}{l}\text { ITS1 } \\
\text { ITS4 }\end{array}$ & $\begin{array}{l}\text { 5'-TCCGTAGGTGAACCTGCGG-3' } \\
5^{\prime} \text {-TCCTCCGCTTATTGATATGC-3' }\end{array}$ & 500 & 95 & 5 & 94 & 0.5 & 58 & 0.5 & 72 & 1.5 & 72 & 7 & $\begin{array}{l}\text { Gardes and Bruns 1993; } \\
\text { White et al. } 1990\end{array}$ \\
\hline $\mathrm{ACT}$ & ACT-512F & 5'-ATGTGCAAGGCCGGTTTCGC-3' & 300 & 95 & 5 & 94 & 0.5 & 59 & 0.5 & 72 & 1.5 & 72 & 7 & Carbone and Kohn 1999 \\
\hline $\mathrm{ACT}$ & ACT-783R & 5'-TACGAGTCCTTCTGGCCCAT-3' & & & & & & & & & & & & \\
\hline GAPDH & GDF-1 & 5'-GCCGTCAACGACCCCTTCATTGA-3' & 300 & 95 & 5 & 94 & 0.5 & 56 & 0.5 & 72 & 1.5 & 72 & 7 & Templeton et al. 1992 \\
\hline GAPDH & GDR1 & 5'-GGGTGGAGTCGTACTTGAGCATGT-3' & & & & & & & & & & & & \\
\hline CHS-1 & CHSI-79F & 5'-TGGGGCAAGGATGCTTGGAAGAAG- $3^{\prime}$ & 300 & 95 & 5 & 94 & 0.5 & 56 & 0.5 & 72 & 1.5 & 72 & 7 & Carbone and Kohn 1999 \\
\hline $\mathrm{CH}-1$ & CHSI-354R & 5'-TGGAAGAACCATCTGTGAGAGTTG-3' & & & & & & & & & & & & \\
\hline
\end{tabular}

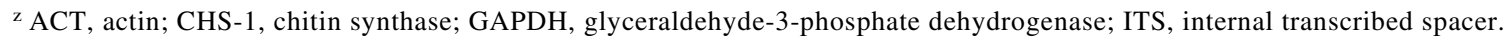


unclear, and additional studies are necessary in the future. It is necessary to conduct further studies on infection time; infecting walnut independently or collaboratively; and disease occurrence patterns of $C$. siamense, $C$. fructicola, and $C$. gloeosporioides s.s.

There was a high variability of virulence among the isolates of the same species (C. siamense, $C$. godetiae, and $C$. fioriniae), which caused walnut anthracnose (Da Lio et al. 2018; Wang et al. 2017). In this paper, virulence varied among isolates of $C$. gloeosporioides s.s. based on inoculation on walnut leaves or fruits. However, the virulence of the isolates to walnut fruits was different between $C$. gloeosporioides s.s. and $C$. siamense. The virulence of $C$. siamense isolates to walnut fruits was similar, whereas the virulence of $C$. gloeosporioides s.s. isolates was significantly different. Even if the isolates were from the same geographic origin, the virulence of the isolates to walnut leaves or fruits showed a great discrepancy, and it appeared that the virulence differences were not correlated with geographic origins. Compared with the virulence to walnut leaves and fruits, $C$. gloeosporioides s.s. and $C$. siamense were more aggressive to walnut fruits than leaves. From the perspective of pathogen characters, the results probably explained why walnut anthracnose caused serious damage in some orchards, whereas much less damage occurred in other orchards. However, the results need be further confirmed by artificially inoculating living walnut trees in the fields. The virulence of isolates from different tissues in the same orchards remains unknown and needs further study.

For controlling walnut anthracnose, the main management strategy was to rely mainly on timely application of fungicides. We determined the sensitivities of $C$. gloeosporioides s.s. isolates to fungicides, including difenoconazole, tebuconazole, flusilazole, and carbendazim, in this paper. Although the number of isolates was relatively restricted, the results still showed that there were differences in resistance ratio to carbendazim and tebuconazole among all isolates. The resistance ratios to carbendazim and tebuconazole were from 1 to 87.3 and from 1 to 51.6, respectively. Isolates SL31, SL-34, SL-30, and SL-37 were from Shangluo county, Shaanxi province, and the resistance ratios to tebuconazole were 1, 6, 16.2, and 38.9, respectively. Carbendazim and tebuconazole were extensively used to control walnut anthracnose disease, and the differences of sensitivities were perhaps consistent with frequency of the carbendazim or tebuconazole usage locally. The sensitivities of $C$. gloeosporioides and $C$. acutatum to carbendazim were different (Cao et al. 2017). Meanwhile, our study indicated that isolates of C. gloeosporioides s.s. displayed differential sensitivities to carbendazim. The results reflected the sensitivities of $C$. gloeosporioides s.s. causing walnut anthracnose to fungicides to some extent. To increase the control effect, it is important for practitioners to ascertain the isolate sensitivities to fungicides. Based on the $\mathrm{EC}_{50}$ values and resistance ratio, difenoconazole and flusilazole would be expected to provide better control than carbendazim and tebuconazole in a given plantation. However, the efficacies need to be verified with more field trials in the future. For controlling walnut anthracnose effectively, it is imperative to identify the pathogen accurately. Meanwhile, it is also necessary to determine fungicide sensitivities of the different isolates of the same fungal taxon. Fungicides should be cautiously chosen for the disease management, and fungicides with different mechanisms should be used in rotation.

In conclusion, the 13 isolates from the orchards were C. gloeosporioides s.s. All of the isolates had been confirmed to be the pathogen of walnut anthracnose in China. The isolates from different geographic regions showed differences in virulence and fungicide sensitivities. The results preliminarily indicated that there was a high intraspecific diversity among the populations of $C$. gloeosporioides s.s. The study provided crucial information for managing this disease in China. For example, the targeted control strategy should be implemented in accordance with the different geographic regions to reduce the losses caused by $C$. gloeosporioides s.s.

\section{Acknowledgments}

We are grateful to Li-ying Chen, Hua-bing Ma, Xing-hong Liu, Chun-hua Duan, Yin Liu, Jing Wang, and Qun Zhu for their assistance in sample collections, and we express our appreciation to Dr. James LaMondia (the Connecticut Agricultural Experiment Station, United States) for reviewing the revised manuscript.

\section{Literature Cited}

Alvarez, M. 1976. Primer catalogo de enfermedades de plantas Mexicanas. Fitofilo 71:1-169.

Blomhoff, R., Carlsen, M. H., Andersen, L. F., and Jacobs, D. R. 2006. Health benefits of nuts: Potential role of antioxidants. Br. J. Nutr. 96(S2):S52-S60.

Cai, L., Hyde, K. D., Taylor, P., Weir, B. S., Waller, J. M., Abang, M. M., Zhang, J. Z., Yang, Y. L., Phoulivong, S., and Liu, Z. Y. 2009. A polyphasic approach for studying Colletotrichum. Fungal Divers. 39:183-204.

Cannon, P. F., Damm, U., Johnston, P. R., and Weir, B. S. 2012 Colletotrichum - current status and future directions. Stud. Mycol. 73:181-213.

Cao, X. R., Xu, X. M., Che, H. Y., West, J. S., and Luo, D. Q. 2017. Distribution and fungicide sensitivity of Colletotrichum species complexes from rubber tree in Hainan, China. Plant Dis. 101:1774-1780.

Carbone, I., and Kohn, L. M. 1999. A method for designing primer sets for speciation studies in filamentous ascomycetes. Mycologia 91:553-556.

Chen, D., Shi, H. J., Wu, H. M., Xu, Z. H., and Zhang, C. Q. 2013. Resistance of Colletotrichum gloeosporioides causing grape ripe rot to thiophanate-methyl and tebuconazole in Zhejiang. J. Fruit Sci. 30:665-668.

Chen, M. M. 2003. Forest Fungi Phytogeography: Forest Fungi Phytogeography of China, North America, and Siberia and International Quarantine of Tree Pathogens. Pacific Mushroom Research \& Education Center, Sacramento, CA.

Cho, W. D., and Shin, H. D. 2004. List of Plant Diseases in Korea. Korean Society of Plant Pathology, Seoul, Korea.

Choi, Y. W., Hyde, K. D., and Ho, W. H. 1999. Single spore isolation of fungi. Fungal Divers. 3:29-38.

Corda, A. C. I. 1831. Die Pilze Deutschlands. Pages 33-64 in: Deutschlands Flora in Abbildungen nach der Natur mit Beschreibungen, Vol. 3. J. Sturm, ed. Sturm, Nürnberg, Germany.

Cortés, B., Núñez, I., Cofán, M., Gilabert, R., Pérez-Heras, A., Casals, E. Deulofeu, R., and Ros, E. 2006. Acute effects of high-fat meals enriched with walnuts or olive oil on postprandial endothelial function. J. Am. Coll. Cardiol. 48:1666-1671.

Crous, P. W., Phillips, A. J. L., and Baxter, A. P. 2000. Phytopathogenic Fungi from South Africa. University of Stellenbosch, Department of Plant Pathology Press, Stellenbosch, South Africa.

Da Lio, D., Cobo-Díaz, J. F., Masson, C., Chalopin, M., Kebe, D., Giraud, M., Verhaeghe, A., Nodet, P., Sarrocco, S., and Le Floch, G. 2018. Combined metabarcoding and multi-locus approach for genetic characterization of Colletotrichum species associated with common walnut (Juglans regia) anthracnose in France. Sci. Rep. 8:10765.

Damm, U., Baroncelli, R., Cai, L., Kubo, Y., O’Connell, R., Weir, B., Yoshino, K. and Cannon, P. F. 2010. Colletotrichum: Species, ecology and interactions. IMA Fungus 1:161-165.

Damm, U., Cannon, P. F., Woudenberg, J. H. C., and Crous, P. W. 2012. The Colletotrichum acutatum species complex. Stud. Mycol. 73:37-113.

Dar, R. A., Rai, A. N., and Shiekh, I. A. 2018. Isolation and mycotaxonomic characterization of Colletotrichum lillacola: A novel species causing anthracnose of Bergenia ligulata. Proc. Indian Natl. Sci. Acad. Part B 88:1615-1620.

de Silva, D. D., Groenewald, J. Z., Crous, P. W., Ades, P. K., Nasruddin, A., Mongkolporn, O., and Taylor, P. W. J. 2019. Identification, prevalence and pathogenicity of Colletotrichum species causing anthracnose of Capsicum annuum in Asia. IMA Fungus 10:8.

Dean, R., Van Kan, J. A., Pretorius, Z. A., Hammond-Kosack, K. E., Di Pietro, A., Spanu, P. D., Rudd, J. J., Dickman, M., Kahmann, R., and Ellis, J. 2012. The top 10 fungal pathogens in molecular plant pathology. Mol. Plant Pathol. 13: 414-430.

Deng, W. P., Du, F., Yang, M., Yang, J. Z., He, X. H., Wang, H. N., Li, C. Y., and Zhu, S. S. 2015. The genetic diversity of Colletotrichum spp. population isolated from grapes in Yunnan province. Yunnan Nong Ye Da Xue Xue Bao 30:173-184

Douanla-Meli, C., and Unger, J. G. 2017. Phylogenetic study of the Colletotrichum species on imported citrus fruits uncovers a low diversity and a new species in the Colletotrichum gigasporum complex. Fungal Biol. 121:858-868.

Fan, K., Wang, J. B., Fu, L., Li, X. J., Zhang, Y., Zhang, X. D., Zhai, H., and Qu, J. L. 2016. Sensitivity of Botryosphaeria dothidea from apple to tebuconazole in China. Crop Prot. 87:1-5.

Freeman, S., Katan, T., and Shabi, E. 1996. Characterization of Colletotrichum gloeosporioides isolates from avocado and almond fruits with molecular and pathogenicity tests. Appl. Environ. Microbiol. 62:1014-1020.

Fu, M., Crous, P. W., Bai, Q., Zhang, P. F., Xiang, J., Guo, Y. S., Zhao, F. F., Yang, M. M., Hong, N., Xu, W. X., and Wang, G. P. 2019. Colletotrichum species associated with anthracnose of Pyrus spp. in China. Persoonia 42:1-35.

Gadgil, P. D., Dick, M. A., Hood, I. A., and Pennycook, S. R. 2005. Fungi on Trees and Shrubs in New Zealand. PressFungi of New Zealand. Fungal Diversity Press, Hong Kong.

Gan, P., Tsushima, A., Hiroyama, R., Narusaka, M., Takano, Y., Narusaka, Y., Kawaradani, M., Damm, U., and Shirasu, K. 2019. Colletotrichum shisoi sp. nov., an anthracnose pathogen of Perilla frutescens in Japan: Molecular phylogenetic, morphological and genomic evidence. Sci. Rep. 9:13349. 
Gardes, M., and Bruns, T. D. 1993. ITS primers with enhanced specificity for basidiomycetes-application to the identification of mycorrhizae and rusts. Mol. Ecol. 2:113-118.

Gorter, G. J. M. A. 1977. Index of plant pathogens and the diseases they cause in cultivated plants in South Africa. Technical Service, Science Bulletin 392. Department of Agriculture, Government Print, Pretoria, South Africa.

He, L. F., Li, X. X., Gao, Y. Y., Li, B. X., Mu, W., and Liu, F. 2019. Characterization and fungicide sensitivity of Colletotrichum spp. from different hosts in Shandong, China. Plant Dis. 103:34-43.

Honger, J. O., Offei, S. K., Oduro, K. A., Odamtten, G. T., and Nyaku, S. T. 2016. Identification and molecular characterisation of Colletotrichum species from avocado, citrus and pawpaw in Ghana. S. Afr. J. Plant Soil 33:177-185.

Huang, L., Li, Q.-C., Zhang, Y., Li, D.-W., and Ye, J.-R. 2016. Colletotrichum gloeosporioides sensu stricto is a pathogen of leaf anthracnose on evergreen spindle tree (Euonymus japonicus). Plant Dis. 100:672-678.

Jayawardena, R. S., Camporesi, E., Elgorban, A. M., Bahkali, A. H., Yan, J. Y., and Hyde, K. D. 2017. A new species of Colletotrichum from Sonchus sp. in Italy. Phytotaxa 314:55-63.

Jayawardena, R. S., Hyde, K. D., Damm, U., Cai, L., Liu, M., Li, X. H., Zhang, W., Zhao, W. S., and Yan, J. Y. 2016. Notes on currently accepted species of Colletotrichum. Mycosphere 7:1192-1260.

Juhásová, G., Ivanová, H., and Spišák, J. 2005. Occurrence and spread of the parasitic microscopic fungi on walnut (Juglans regia L.) on various localities of Slovakia. Environ. Health Perspect. 113:345-352.

Khan, A. A., and Kundoo, A. A. 2018. Pests of Walnut. Springer, Singapore.

Kobayashi, T. 2007. Index of Fungi Inhabiting Woody Plants in Japan-Host, Distribution and Literature. The National Rural Education Association, Zenkoku-Noson-Kyoiku Kyokai Publishing Co. Ltd. Tokyo, Japan.

Kumar, S., Stecher, G., and Tamura, K. 2016. MEGA7: Molecular evolutionary genetics analysis version 7.0 for bigger datasets. Mol. Biol. Evol. 33:1870-1874.

Lee, S.-Y., and Jung, H.-Y. 2018. Colletotrichum kakivorum sp nov., a new leaf spot pathogen of persimmon in Korea. Mycol. Prog. 17:1113-1121.

Liu, W., Yin, P., Wang, Z. H., and Ye, N. X. 2017. Genetic differentiation of Colletotrichum of tea and other woody plants. Jiangsu Agric. Sci. 45:42-44.

Liu, X. Y., Jing, Y., and Yang, J. X. 1995. A study on Colletotrichum classification of wooden plant in Shaanxi province. J. Northwest For. Coll. 3:29-30.

Manire, C. A., Rhinehart, H. L., Sutton, D. A., Thompson, E. H., Rinaldi, M. G., Buck, J. D., and Jacobson, E. 2002. Disseminated mycotic infection caused by Colletotrichum acutatum in a Kemp's ridley sea turtle (Lepidochelys kempi). J. Clin. Microbiol. 40:4273-4280.

Marin-Felix, Y., Groenewald, J. Z., Cai, L., Chen, Q., Marincowitz, S., Barnes, I., Bensch, K., Braun, U., Camporesi, E., Damm, U., de Beer, Z. W., Dissanayake, A., Edwards, J., Giraldo, A., Hernandez-Restrepo, M., Hyde, K. D., Jayawardena, R. S., Lombard, L., Luangsa-ard, J., McTaggart, A. R., Rossman, A. Y., Sandoval-Denis, M., Shen, M., Shivas, R. G., Tan, Y. P., van der Linde, E. J., Wingfield, M. J., Wood, A. R., Zhang, J. Q., Zhang, Y., and Crous, P. W. 2017. Genera of phytopathogenic fungi: GOPHY 1. Stud. Mycol. 86:99-216.

O'Connell, R. J., Thon, M. R., Hacquard, S., Amyotte, S. G., Kleemann, J., Torres, M. F., Damm, U., Buiate, E. A., Epstein, L., and Alkan, N. 2012. Lifestyle transitions in plant pathogenic Colletotrichum fungi deciphered by genome and transcriptome analyses. Nat. Genet. 44:1060-1065.

Pennycook, S. R. 1989. Plant Diseases Recorded in New Zealand. Plant Diseases Division, DSIR, Auckland, New Zealand.

Qu, W. W., Yang, K. Q., Liu, H. X., and Hou, L. Q. 2011. Main diseases of walnut and integrated management in Shandong. Plant Prot. 44:136-140.

Savian, L., Muniz, M. F. B., Poletto, T., Maculan, L., Rabuske, J., Blume, E., and Sarzi, J. 2019. First report of Colletotrichum nymphaeae causing anthracnose on Juglans regia fruits in southern Brazil. Plant Dis. 103:3287.
Sharma, G., Maymon, M., and Freeman, S. 2017. Epidemiology, pathology and identification of Colletotrichum including a novel species associated with avocado (Persea americana) anthracnose in Israel. Sci. Rep. 7:15839.

Simmonds, J. H. 1966. Host Index of Plant Diseases in Queensland. Queensland Department of Primary Industries, Brisbane, Queensland, Australia

Sreenivasaprasad, S., and Talhinhas, P. 2005. Genotypic and phenotypic diversity in Colletotrichum acutatum, a cosmopolitan pathogen causing anthracnose on a wide range of hosts. Mol. Plant Pathol. 6:361-378

Sun, Y. C., Damm, U., and Huang, C. J. 2019. Colletotrichum plurivorum, the causal agent of anthracnose fruit rot of Papaya in Taiwan. Plant Dis. 103:1040.

Templeton, M. D., Rikkerink, E. H. A., Solon, S. L., and Crowhurst, R. N. 1992 Cloning and molecular characterization of the glyceraldehyde-3-phosphate dehydrogease encoding gene and cDNA from the plant pathogenic fungus Glomerella cingulata. Gene 122:225-230.

Than, P. P., Shivas, R. G., Jeewon, R., Pongsupasamit, S., Marney, T. S., Taylor, P. W. J., and Hyde, K. D. 2008. Epitypification and phylogeny of Colletotrichum acutatum J.H. Simmonds. Fungal Divers. 28:97-108.

Tian, S. B., Jin, X. R., Zhao, S. E., Zhang, W. Z., Cao, W. H., and Huo, Y. H. 1991. Control of Atrijuglans hetaohei Yang by method of high-pressure injection. Acta Agric. Boreali-sinica 6:158-161.

Wang, Q. H., Fan, K., Li, D. W., Niu, S. G., Hou, L. Q., and Wu, X. Q. 2017. Walnut anthracnose caused by Colletotrichum siamense in China. Australas. Plant Pathol. 46:585-595.

Wang, Q. H., Li, D. W., Duan, C. H., Liu, X. H., Niu, S. G., Hou, L. Q., and Wu, X. Q. 2018. First report of walnut anthracnose caused by Colletotrichum fructicola in China. Plant Dis. 102:247.

Wang, Q. H., Liu, X. H., Fan, K., Duan, C. H., Niu, S. G., and Wu, X. Q. 2016. Identification and biological characteristics of pathogen from Colletotrichum gloeosporioides. J. Shandong Agric. Univ. 47:9-14.

Wang, Q. Q., and Tang, G. H. 2018. The mitochondrial genomes of two walnut pests, Gastrolina depressa depressa and $G$. depressa thoracica (Coleoptera: Chrysomelidae), and phylogenetic analyses. PeerJ 6:e4919.

Weir, B. S., Johnston, P. R., and Damm, U. 2012. The Colletotrichum gloeosporioides species complex. Stud. Mycol. 73:115-180.

White, T. J., Bruns, T., Lee, S., and Taylor, J. 1990. Amplification and direct sequencing of fungal ribosomal RNA genes for phylogenetics. Pages 315-322 in: PCR Protocols: A Guide to Methods and Applications. M. Gelfand, J. Sninsky, and T. J. White, eds. Academic Press, San Diego, CA.

Xiao, Y. G., Zhou, J. H., and Xiao, Y. B. 2010. Research on the biologic features of pathogenic bacteria of walnut anthracnose and its control techniques in the Qinba mountain. J. Sichuan Forestry Sc. Tech. 31:54-57.

Xu, H., Zhou, R., Fu, J., Yuan, Y., Ge, X., and Damm, U. 2018. Colletotrichum atractylodicola sp nov.: The anthracnose pathogen of Atractylodes chinensis in China. Mycol. Prog. 17:393-402.

Yang, Y. L., Liu, Z. Y., Cai, L., Hyde, K. D., Yu, Z. N., and McKenzie, E. H. C. 2009 Colletotrichum anthracnose of Amaryllidaceae. Fungal Divers. 39:123-146.

Zhang, X. C., Xiao, Q., Gao, Z. Y., and Wang, J. B. 2014a. The detection of pathogenicity for Colletotrichum from different litchi cultivars and regions. J. Fruit Sci. 31:296-301

Zhang, X. Y., Li, X., and Gao, Z. Y. 2014b. Carbendazim resistance of Colleotrichum gloeosporioides on tropical and subtropical fruits. Chin. J. Trop. Agric. 34:71-74.

Zhu, Y. F., Yin, Y. F., Qu, W. W., and Yang, K. Q. 2014. Occurrence and spread of the pathogens on walnut (Juglans regia) in Shandong Province, China. Acta Hortic. 1050:347-351

Zhu, Y. Z., Liao, W. J., Zou, D. X., Wu, Y. J., and Zhou, Y. 2015. First report of leaf spot disease on walnut caused by Colletotrichum fioriniae in China. Plant Dis. 99:289. 